Proc. Estonian Acad. Sci. Biol. Ecol., 2005, 54, 4, 315-322

\title{
Enchytraeid communities in grasslands on peat at different groundwater levels
}

\begin{abstract}
Wim Didden and Jerry van Dijk
Department of Systems Ecology, Institute of Ecological Science, Free University Amsterdam, de Boelelaan 1085, 1081 HV Amsterdam, the Netherlands Present address: Institute of Environmental Sciences, P.O. Box 9518, 2300 RA Leiden, the Netherlands; vandijk@cml.leidenuniv.nl

Received 12 October 2004, in revised form 23 February 2005

Abstract. In the Netherlands, wetland restoration projects involve the rewetting of former agricultural grasslands, where low water levels are artificially maintained (polders). We studied the effects of rewetting on the enchytraeid community in grasslands on acid peat soil $(\mathrm{pH}=3.7)$. Rewetting was established by hydrologically isolating the restoration areas from the polders. After isolation, the natural seepage conditions of the area caused a clear rise in the groundwater level. At the same time, because of the different quality of the seepage water, the soil $\mathrm{pH}$ rose to 5.2-6.7. Sampling was carried out in 2002, four years after the start of the project. It was found that differences in the total abundance and biomass between the enchytraeid communities were not significant. However, there were clear changes in the species composition and diversity. The control site was dominated by Cognettia sphagnetorum, and the rewetted sites by Fridericia species (notably F. galba and $F$. perrieri). The diversity was clearly higher in the rewetted sites. In general, the depth distribution of enchytraeid species was not affected by rewetting, Marionina argentea being a notable exception.
\end{abstract}

Key words: Enchytraeidae, colonization, wetlands, groundwater, decomposition, $\mathrm{pH}$.

\section{INTRODUCTION}

Up to the middle of the 20th century, oligotrophic peaty wetlands formed an important part of the landscape in the western and central parts of the Netherlands. Since then, due to increasing population pressure and intensification of agriculture, the area occupied by wetlands has diminished considerably. As the awareness of the value of such ecosystems has increased many wetland protection and restoration projects are being carried out at present. One approach consists in 
rewetting ungrazed pastures in polders on peat soils by stopping the mechanical drainage. In such projects it is expected that the naturally occurring seepage of base-rich groundwater will re-create anoxic conditions in the soil, thereby reducing decomposition rates and nutrient availability. Often, however, such projects do not result in reduced nutrient availability, and the reasons for this are still under study. This study describes the changes in the composition of enchytraeid communities 4 years after the start of one of these projects.

\section{METHODS AND MATERIALS}

\section{The sites}

The rewetting project under study was set up in 1998 in the Horstermeerpolder $\left(52^{\circ} 14^{\prime} \mathrm{N}, 05^{\circ} 04^{\prime} \mathrm{E}\right.$; see Fig. 1). The soil was a clayey peat, with a peat layer of $\pm 2 \mathrm{~m}$. To study the rewetting effects, three sites were selected: one drained control site (groundwater level at $-40 \mathrm{~cm}$ ) and two differently rewetted sites (groundwater level $-32 \mathrm{~cm}$ and $-17 \mathrm{~cm}$, respectively). The change in the groundwater level was the only modification made. Table 1 shows some characteristics of the sites.

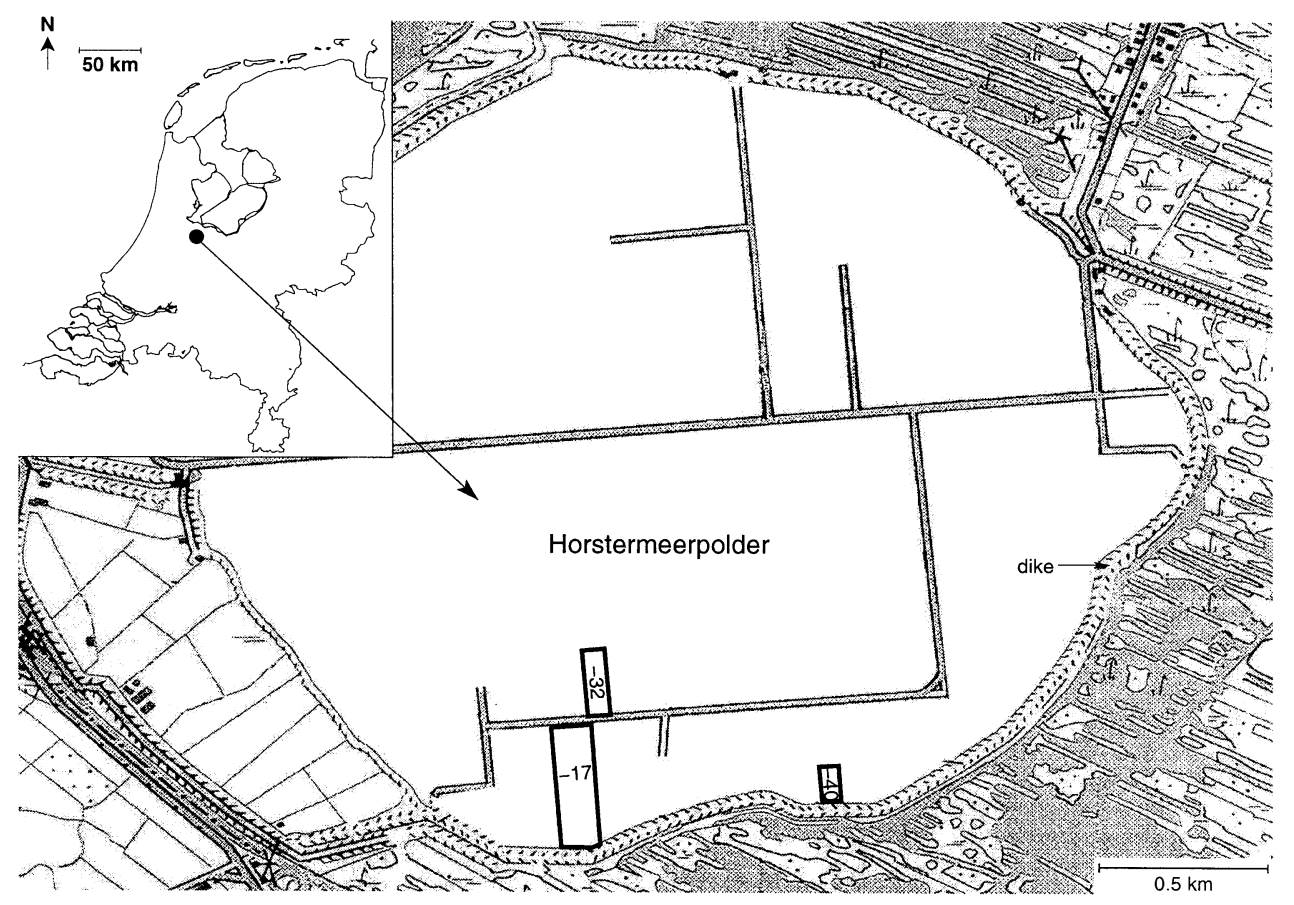

Fig. 1. Location of the study area. 
Table 1. Some characteristics of the experimental sites at different groundwater levels. Different superscripts within a row indicate significant $(P<0.05)$ differences in post hoc $t$-tests. CTSL cotton strip tensile strength loss. Data from van Dijk et al. 2004, who also listed the methods used

\begin{tabular}{|c|c|c|c|}
\hline & $-40 \mathrm{~cm}$ & $-32 \mathrm{~cm}$ & $-17 \mathrm{~cm}$ \\
\hline Soil pH & $3.8^{\mathrm{a}}$ & $6.5^{\mathrm{b}}$ & $6.0^{\mathrm{c}}$ \\
\hline Soil redox potential, $\mathrm{mV}$ & $474.8^{\mathrm{a}}$ & $176.3^{\mathrm{b}}$ & $233.1^{\mathrm{a}}$ \\
\hline Extractable $\mathrm{PO}_{4}, \mathrm{mg} \mathrm{P} \mathrm{kg}^{-1}$ dry soil & $123.4^{\mathrm{a}}$ & $243.8^{\mathrm{b}}$ & $511.8^{\mathrm{c}}$ \\
\hline CTSL $0-10 \mathrm{~cm}, \%$ strength loss day ${ }^{-1}$ & $1.9^{\mathrm{a}}$ & $2.9^{\mathrm{b}}$ & $3.0^{\mathrm{b}}$ \\
\hline CTSL $10-20 \mathrm{~cm}, \%$ strength loss day ${ }^{-1}$ & $1.1^{\mathrm{a}}$ & $2.1^{\mathrm{b}}$ & $2.1^{\mathrm{b}}$ \\
\hline
\end{tabular}

\section{Sampling, extraction, and identification}

Sampling for enchytraeids took place on 23 April 2002. At each site 10 randomly selected samples were taken with a steel corer $(\varnothing 4.8 \mathrm{~cm})$ to a depth of $12.5 \mathrm{~cm}$. The samples were transported to the laboratory, where they were stored at $4{ }^{\circ} \mathrm{C}$ for a maximum of 50 days. Prior to extraction (automated O'Connor extraction) the samples were divided in $2.5 \mathrm{~cm}$ depth increments, which were extracted separately. The worms were identified alive, and their individual lengths were measured to the nearest millimetre for biomass calculations.

\section{Statistical and numerical analysis}

After log-transformation of abundance and biomass data, statistical analysis was done using correlation and ANOVA procedures with post hoc $t$-tests (Statistica 5.1) and correspondence analysis (CANOCO 4.5).

\section{RESULTS}

Overall, 26 species of Enchytraeidae were recorded, only 3 of which occurred in all sites. Two species of Tubificidae were found: Rhyacodrilus falciformis, Bretscher, 1901 in all three sites, and a Limnodrilus species in the site with groundwater level of $-32 \mathrm{~cm}$. Table 2 shows the enchytraeid species recorded from each site, their abundances, several general characteristics of the enchytraeid communities, and the results of post hoc tests on abundances. From this table it appears that there was a significant increase in diversity in the rewetted sites, accompanied by a decrease in the total abundance of enchytraeids. The control site was dominated by Cognettia sphagnetorum, whereas in the rewetted sites Fridericia species dominated, $F$. galba at the groundwater level of $-32 \mathrm{~cm}$ and $F$. perrieri at $-17 \mathrm{~cm}$. There were no significant differences between the sites in the total biomass, reflecting the occurrence of many medium-sized worms in the control site versus fewer but larger-sized worms in the rewetted sites. Correspondence analysis 
Table 2. Abundance (no $\mathrm{m}^{-2}$ ) of enchytraeid species, biomass $\left(\mathrm{g} \mathrm{FW} \mathrm{m}^{-2}\right)$, number of genera and species, and diversity (Shannon's H) in the experimental sites at different groundwater levels. Different superscripts within a row indicate significant $(P<0.05)$ differences in post hoc $t$-tests

\begin{tabular}{|c|c|c|c|}
\hline & $-40 \mathrm{~cm}$ & $-32 \mathrm{~cm}$ & $-17 \mathrm{~cm}$ \\
\hline Achaeta Vejdovský, 1878 (juv.) & $8900^{\mathrm{a}}$ & $60^{\mathrm{b}}$ & $0^{\mathrm{b}}$ \\
\hline A. affinis Nielsen \& Christensen, 1959 & $390^{\mathrm{a}}$ & $0^{\mathrm{b}}$ & $0^{\mathrm{b}}$ \\
\hline A. camerani (Cognetti, 1899) & 170 & 0 & 0 \\
\hline A. parva Nielsen \& Christensen, 1961 & 500 & 60 & 0 \\
\hline Bryodrilus Ude, 1892 (juv.) & 0 & 0 & 220 \\
\hline Buchholzia appendiculata (Buchholz, 1862) & $1200^{\mathrm{a}}$ & $4600^{\mathrm{b}}$ & $3000^{\mathrm{a}}$ \\
\hline Cernosvitoviella Nielsen \& Christensen, 1959 (juv.) & 1800 & 330 & 1600 \\
\hline C. atrata (Bretscher, 1903) & $0^{\mathrm{a}}$ & $170^{\mathrm{ab}}$ & $2100^{\mathrm{b}}$ \\
\hline Cognettia Nielsen \& Christensen, 1959 (juv.) & 0 & 220 & 60 \\
\hline C. glandulosa (Michaelsen, 1888) & 0 & 660 & 940 \\
\hline C. sphagnetorum (Vejdovský, 1878) & $37000^{\mathrm{a}}$ & $0^{\mathrm{b}}$ & $0^{\mathrm{b}}$ \\
\hline Enchytraeus Henle, 1837 (juv.) & $4600^{\mathrm{a}}$ & $11000^{\mathrm{b}}$ & $14000^{\mathrm{b}}$ \\
\hline E. christenseni Dózsa-Farkas, 1992 & $1400^{\mathrm{a}}$ & $2400^{\mathrm{b}}$ & $4150^{\mathrm{b}}$ \\
\hline Fridericia Michaelsen, 1889 (juv.) & $1200^{\mathrm{a}}$ & $14000^{\mathrm{b}}$ & $11000^{\mathrm{b}}$ \\
\hline F. benti Schmelz, 2002 & 0 & 170 & 0 \\
\hline F. bulboides Nielsen \& Christensen, 1959 & 0 & 110 & 0 \\
\hline F. parathalassia Schmelz, 2002 & 0 & 170 & 60 \\
\hline F. galba (Hoffmeister, 1843) & $0^{\mathrm{a}}$ & $1600^{\mathrm{b}}$ & $830^{\mathrm{c}}$ \\
\hline F. minor Friend, 1913 & 0 & 0 & 60 \\
\hline F. hegemon (Vejdovský, 1878) & 0 & 170 & 60 \\
\hline F. isseli Rota, 1994 & 0 & 330 & 0 \\
\hline F. paroniana Issel, 1904 & 330 & 60 & 0 \\
\hline F. perrieri (Vejdovský, 1878) & $0^{\mathrm{a}}$ & $940^{\mathrm{b}}$ & $5300^{\mathrm{b}}$ \\
\hline Hemifridericia Nielsen \& Christensen, 1959 (juv.) & 0 & 0 & 110 \\
\hline H. parva Nielsen \& Christensen, 1959 & 0 & 220 & 110 \\
\hline Henlea perpusilla Friend, 1911 & $0^{\mathrm{a}}$ & $110^{\mathrm{ab}}$ & $1200^{\mathrm{b}}$ \\
\hline H. ventriculosa (d'Udekem, 1854) & $0^{\mathrm{a}}$ & $330^{\mathrm{a}}$ & $1300^{\mathrm{b}}$ \\
\hline Lumbricillus Ørsted, 1844 (juv.) & 60 & 0 & 60 \\
\hline Marionina Michaelsen, 1890 (juv.) & $9000^{\mathrm{a}}$ & $5000^{\mathrm{ab}}$ & $3500^{\mathrm{b}}$ \\
\hline M. appendiculata Nielsen \& Christensen, 1959 & $0^{\mathrm{a}}$ & $5000^{\mathrm{b}}$ & $440^{\mathrm{a}}$ \\
\hline M. argentea (Michaelsen, 1889) & 3300 & 2100 & 2900 \\
\hline M. clavata Nielsen \& Christensen, 1961 & $7600^{\mathrm{a}}$ & $0^{\mathrm{b}}$ & $0^{\mathrm{b}}$ \\
\hline M. communis Nielsen \& Christensen, 1959 & 0 & 170 & 0 \\
\hline M. filiformis Nielsen \& Christensen, 1959 & 60 & 0 & 0 \\
\hline M. riparia Bretscher, 1899 augm. Cernosvitov, 1928 & 0 & 0 & 60 \\
\hline Total abundance, no $\mathrm{m}^{-2}$ & $77510^{\mathrm{a}}$ & $49980^{\mathrm{ab}}$ & $53060^{\mathrm{b}}$ \\
\hline Biomass, $\mathrm{g} \mathrm{FW} \mathrm{m}^{-2}$ & 9.48 & 11.96 & 17.79 \\
\hline Number of genera & $4.6^{\mathrm{a}}$ & $5.1^{\mathrm{ab}}$ & $5.7^{\mathrm{b}}$ \\
\hline Number of species & $5.3^{\mathrm{a}}$ & $7.5^{\mathrm{b}}$ & $6.7^{\mathrm{b}}$ \\
\hline Diversity, Shannon's H & $1.15^{\mathrm{a}}$ & $1.71^{\mathrm{b}}$ & $1.44^{\mathrm{c}}$ \\
\hline
\end{tabular}


based on the species composition (adult specimens only) of the individual samples allowed a clear differentiation to be made between species groups characteristic of the respective sites (Fig. 2a), and between the respective sites (Fig. 2b).

There were no significant differences in the vertical distribution between the three sites, except for Marionina argentea, which had a significantly deeper depth of occurrence in the control site than in the most rewetted site (Fig. 3).
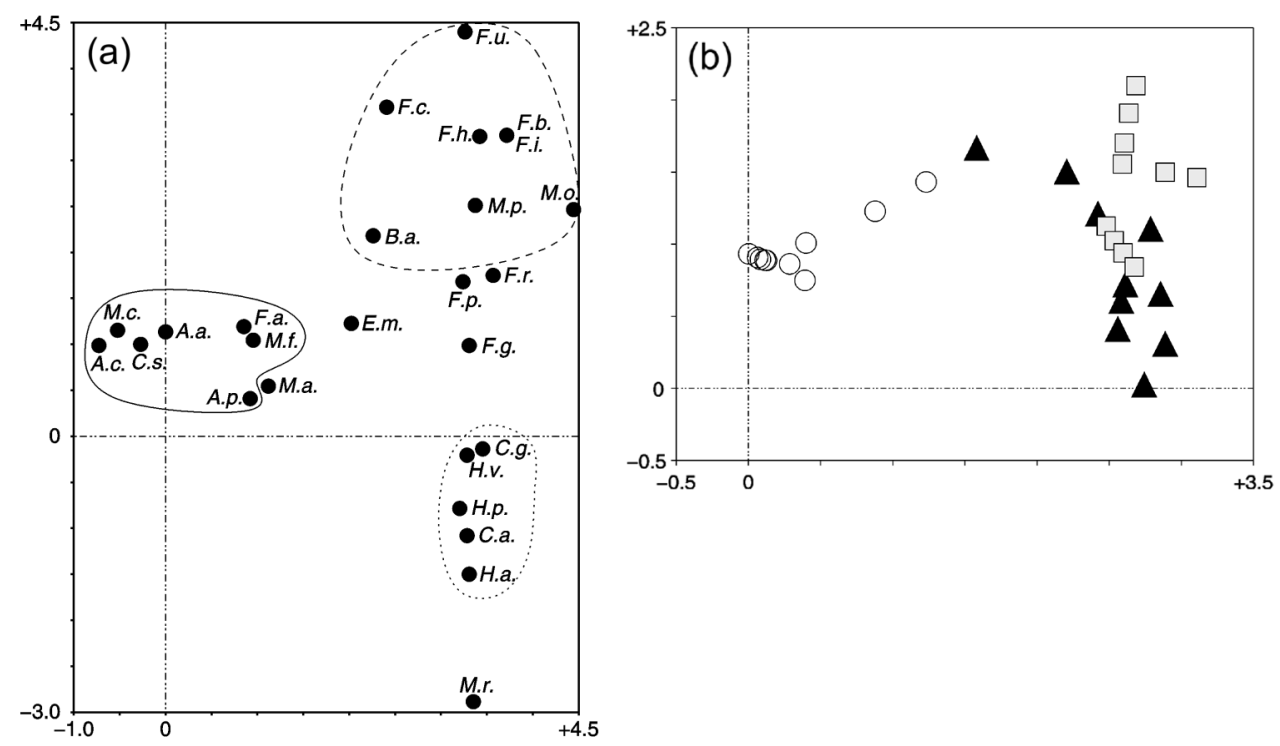

Fig. 2. Results of Detrended Correspondence Analysis (DCA) based on the species composition of individual samples. Data log-transformed, downweighing of rare species applied. The ordination diagrams show the first 2 axes, accounting for $40 \%$ of the variance in the species data. Eigenvalue axis 1: 0.655 , axis 2: 0.214 . Total inertia: 2.170 .

(a) Ordination of species. Species characteristic of each site outlined. Water level $-40 \mathrm{~cm}$ with a solid line, $-32 \mathrm{~cm}$ with a dashed line, and $-17 \mathrm{~cm}$ with a dotted line. Abbreviations used for species names:
A.a.: $\quad$ Achaeta affinis
F.h.: $\quad$ F. hegemon
A.c.: A. camerani
F.i.: $\quad$ F. isseli
A.p.: A. parva
B.a.: Buchholzia appendiculata
F.a.: F.paroniana
F.p.: $\quad$ F.perrieri
C.a.: Cernosvitoviella atrato
H.a.: Hemifridericia parva
C.g.: $\quad$ Cognettia glandulosa
C.s.: $\quad$ C. sphagnetorum
H.p.: $\quad$ Henlea perpusilla
H.v.: $\quad H$. ventriculosa
E.m.: Enchytraeus minutu
M.p.: Marionina appendiculata
F.b.: $\quad$ Fridericia bulbosa
F.u.: $\quad$ F. bulboides
M.a.: $\quad$ M. argentea
F.c.: $\quad$ F. callosa
M.c.: $\quad$ M. clavata
F.g.: $\quad F$. galba
M.o.: M. communis
F.r.: $\quad$ F. gracilis
M.f.: $\quad$ M. filiformis
M.r.: $\quad$ M. riparia

(b) Ordination of individual samples. Empty circles: groundwater table $-40 \mathrm{~cm}$; grey squares: groundwater table $-32 \mathrm{~cm}$; black triangles: groundwater table $-17 \mathrm{~cm}$. 


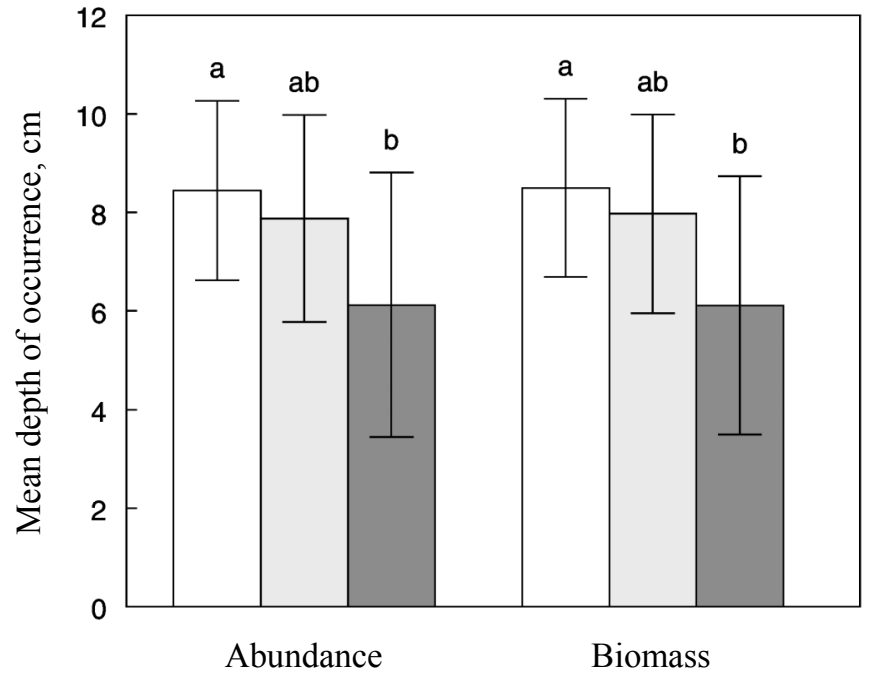

Fig. 3. Mean depth of occurrence ( $\mathrm{cm}$ below surface) and standard deviation of abundance and biomass of $M$. argentea in the experimental sites. Different superscripts above bars indicate significant $(P<0.05)$ differences in post hoc $t$-tests. White bars: groundwater table $-40 \mathrm{~cm}$; light grey bars: groundwater table $-32 \mathrm{~cm}$; dark grey bars: groundwater table $-17 \mathrm{~cm}$.

\section{DISCUSSION}

Quantitative data on enchytraeid communities in grasslands on peat soil are scarce. Beylich \& Graefe (2002) report abundances ranging from ca 12000 to ca $65000 \mathrm{~m}^{-2}$ in four sites, and Didden (2001, unpubl. results) found $28000 \mathrm{~m}^{-2}$ in a single site. The present data appear to fit in this range.

Assuming the control site to represent the drained situation, it is remarkable how drastically the enchytraeid communities in the rewetted sites changed in only four years from a Cognettia-dominated to a Fridericia-dominated community. From a succession series of grassland on peat soil to birch forest Nowak (2001) reported very little change in community composition even after 20 years. In these sites, however, the changes in soil conditions may have been less strong than in the present study. In two investigations (Düker et al. 1999, Frouz et al. 2000) of the succession on recultivated soils on fly-ash and former open coal mines, respectively, Fridericia and Henlea species appeared only after 10 or more years. In these two cases the initial lack of organic matter (food) in the soil may have played an important part. From a restoration project in a Californian salt marsh Levin \& Talley (2002) reported a slow (>3 years) colonization by enchytraeids, despite a clear tidal influence that could have assisted in dispersion. A comparably fast colonization was reported by Jungerius et al. (1995), who found a completely changed enchytraeid community only two years after sod removal in a dune heathland, and by Black et al. (2003) one year after the liming of pasture 
on acid brown soils. In these cases, however, sources of the "new" species may have been nearby.

Prerequisites for a successful colonization are (1) the presence of a suitable habitat (in terms of food and physico-chemical soil conditions), and (2) good dispersive and reproductive abilities. Regarding the first condition it would seem that both rewetted sites could provide ample food, since the organic matter content of these peat soils was high, and rates of decomposition processes were increased after rewetting (van Dijk et al. 2004). This was reflected in the increases in extractable $\mathrm{PO}_{4}$ and in CTSL (Cotton strip Tensile Strength Loss) (Table 1). Moreover, the increase of $\mathrm{pH}$ and decrease of redox potential in the rewetted sites (Table 1) will most probably have contributed to a decline and eventual disappearance of the original acidophilic/acid-tolerant community, thus leaving ample niche space for other species. The speed of colonization of the rewetted sites will therefore largely have depended on the reproduction and dispersion abilities of the species involved, notably Fridericia and Henlea species, and Marionina appendiculata. Especially with Fridericia species this is surprising, as most species from this genus are considered to be rather specialized, K-selected species (e.g. Beylich 2001). Yet, Dózsa-Farkas (1996) reported that many Fridericia species have sexually mature specimens throughout the year and that $F$. galba (maybe also other species?) is capable of reproduction through self-fertilization. Given the relatively short development times of the cocoons, this would allow rapid reproduction under favourable conditions. This would also suggest that at least some species in this genus are less clearly K-selected than generally assumed. As regards the dispersion abilities of enchytraeids, available information suggests that these are low (Salminen \& Sulkava 1996, Christensen et al. 2002). However, it seems unlikely that the speed of colonization as observed in the present case can be sufficiently explained by mechanisms such as transport by water movement or in soil adhering to birds or other larger animals. Further studies into this subject would seem worthwhile.

\section{REFERENCES}

Beylich, A. 2001. Untersuchungen an Enchytraeiden (Oligochaeta) zum Einfluss von Bodenfeuchte und $\mathrm{pH}-$ Wert auf die Toxizität von Schwermetallen im Freiland und in Laborversuchen. Dissertation Freie Universität, Berlin.

Beylich, A. \& Graefe, U. 2002. Annelid coenoses of wetlands representing different decomposer communities. In Wetlands in Central Europe (Broll, G., Merbach, W. \& Pfeiffer, E.-M., eds.), pp. 1-10. Springer, Berlin.

Black, H., Standen, V., Piertney, S., MacDonald, C., Evershed, R. \& Bull, I. 2003. The impact of environmental change on the functional role of enchytraeids in grassland. Newsl. Enchytraeidae, 8, 77-80.

Christensen, B., Pedersen, B. V. \& Hvilsom, M. M. 2002. Persisting clone pool differences in sexual/asexual Buchholzia appendiculata (Enchytraeidae, Oligochaeta) as revealed by genetic markers. Pedobiologia, 46, 90-99.

Dózsa-Farkas, K. 1996. Theorie zur Vermehrungsstrategie einiger Enchytraeiden Arten (Oligochaeta). Newsl. Enchytraeidae, 5, 25-33. 
Düker, C., Keplin, B. \& Hüttl, R. F. 1999. Development of enchytraeid communities in reclaimed lignite mine spoil. Newsl. Enchytraeidae, 6, 77-89.

Frouz, J., Keplin, B., Pizl, V., Tajovsky, K., Stary, J., Lukesová, A., Nováková, A., Balík, V., Hánel, L., Materna, J., Düker, C., Chalupský, J., Rusek, J. \& Heinkele, T. 2000. Soil biota and upper soil layer development in two contrasting post-mining chronosequences. Ecol. Eng., 17, 275-284.

Jungerius, P. D., Koehler, H., Kooijman, A. M., Mücher, H. J. \& Graefe, U. 1995. Response of vegetation and soil ecosystem to mowing and sod removal in the coastal dunes "Zwanewater", the Netherlands. J. Coastal Conserv., 1, 3-16.

Levin, L. A. \& Talley, T. S. 2002. Natural and manipulated sources of heterogeneity controlling early faunal development of a salt marsh. Ecol. Appl., 12, 1785-1802.

Nowak, E. 2001. Enchytraeid communities in successional habitats (from meadow to forest). Pedobiologia, 45, 497-508.

Salminen, J. \& Sulkava, P. 1996. Distribution of soil animals in patchily contaminated soil. Soil Biol. Biochem., 28, 1349-1355.

van Dijk, J., Stroetenga, M., Bos, L., van Bodegom, P. M., Verhoef, H. A. \& Aerts, R. 2004. Restoring natural seepage conditions on former agricultural grasslands does not lead to reduction of organic matter decomposition and soil nutrient dynamics. Biogeochemistry, 71, $317-337$.

\section{Valgeliimuklaste kooslused turbastel rohumaadel erineva põhjaveetaseme puhul}

\section{Wim Didden ja Jerry van Dijk}

Hollandis taastatakse endistel poldriniitudel märgalasid, hoides neid kunstlikult soistena. On uuritud taasniisutamise mõju valgeliimuklaste kooslusele happelisel $(\mathrm{pH} 3,7)$ turbamullal. Katsealad olid poldrist hüdroloogiliselt eraldatud. Neis kerkis põhjaveetase loomuliku läbiimbumise teel, kusjuures vee lisandumisel tõusis mulla pH 5,2-6,7-ni. Usse koguti aastal 2002, neli aastat pärast katse algust. Arvukuse ja biomassi erinevused ei olnud olulised, küll aga erinesid koosluste liigiline koosseis ja mitmekesisus. Võrdlusalal domineeris Cognettia sphagnetorum, taastatud märgalal perekond Fridericia (olulisemad $F$. galba ja $F$. perrieri). Mitmekesisus oli taastatud märgalal selgelt kõrgem. Valgeliimuklaste sügavuslevikule mullas põhjavee tõus oluliselt ei mõjunud; erandiks oli vaid Marionina argentea, kes hoidus pinnale veidi lähemale. 